\title{
Vein of Galen malformation
}

\author{
Mehtab Ahmad, ${ }^{1}$ Shuaib Mir, ${ }^{2}$ Shagufta Wahab, ${ }^{1}$ Imran Rizvi ${ }^{3}$ \\ ${ }^{1}$ Department of Radiodiagnosis, J N Medical College, Aligarh Muslim University, Aligarh, India \\ ${ }^{2}$ Department of Radiodiagnosis, Apollo Hospital, New Delhi, India \\ ${ }^{3}$ General Medicine, J N Medical College, Aligarh Muslim University, Aligarh, Uttar Pradesh, India
}

Correspondence to Dr Imran Rizvi, imranrizvi09@gmail.com

\section{DESCRIPTION}

An 8-month-old baby boy presented to the paediatrics outpatient department with a complaint of enlargement of head size. General and cardiovascular examinations, as well as routine biochemical analysis were within normal limits. There was no evidence of skin lesions to suggest capillary malformation neither there was any limb hypertrophy, also there was no history of skin lesions, limb hypertrophy or vascular malformations in the family. Skull ultrasound (USG) done outside reported a heterogeneous, predominantly hypoechoic lesion in region posterior to third ventricle with dilated lateral and third ventricle and normal-sized fourth ventricle suggestive of obstructive hydrocephalus. Slow flow was also detected within the lesion. MRI was advised, which confirmed the findings of USG, and showed heterogeneous intensity lesion in the pineal region causing mass effect on aqueduct (figure 1). MR angiography and venography were also performed which well delineated the lesion (figure 2).

The vein of Galen (Great cerebral vein or great vein of Galen) is a short vascular trunk formed by the union of the two internal cerebral veins and the basal veins of Rosenthal. Vein of Galen aneurysmal malformation (VGAM) develops due to teratogenic insult during 6-11 weeks of fetal life. ${ }^{1}$ There is persistence of embryonic prosencephalic vein of Markowski, resulting in aneurysmal dilatation of vein of Galen with arteriovenous shunting of blood. Blood shunting may lead to high-output cardiac failure in the infant, which may be a presenting feature of this condition. VGAM can be associated with capillary malformation-arteriovenous malformation (CM-AVM), which is an autosomal dominant disorder due to mutation in RASA1 gene.

Arachnoid cyst, cavum vergae and porencephalic cyst may be included in the differential diagnosis of VGAM. ${ }^{2}$ None of these lesions have any evidence of intralesional flow, so the diagnosis gets almost confirmed on imaging only.

Treatment options for VGAM include embolisation or surgical correction. In a tiny fraction of cases, VGAM (with low-flow state) may get corrected spontaneously, as it gets thrombosed and slowly regresses with time. ${ }^{3}$

Surgery for VGAM has got high death risks, so is now considered in only cases of failure of embolisation or rarely as a complement to endovascular therapy. ${ }^{4}$

Introduction of endovascular therapy has revolutionised the management of VGAM patients. This includes transarterial catheterisation of the femoral artery and occlusion of feeding arteries, or direct transvenous percutaneous embolisation techniques by puncture of the sinus confluence and setting catheter to the aneurysm or by catheterisation of the femoral vein. ${ }^{5}$

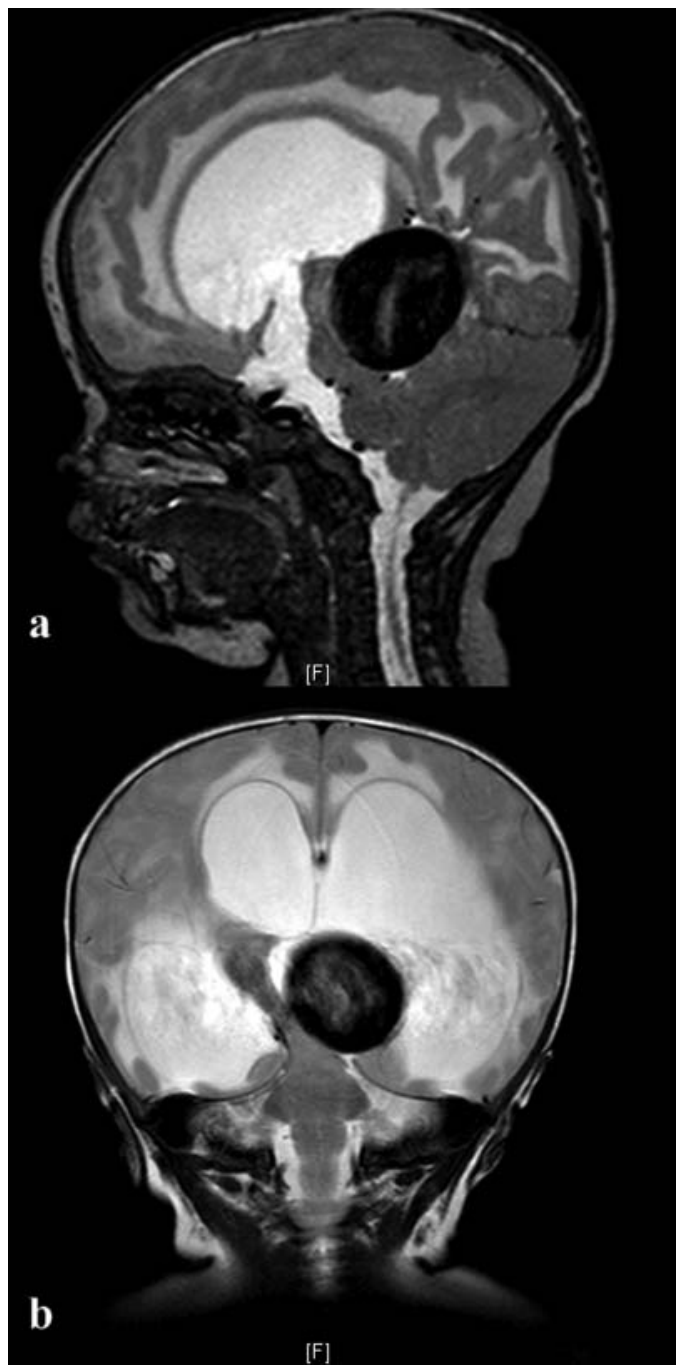

Figure 1 (A and B): Mid-sagittal and coronal T2-weighted images showing a large flow void in midline posterior to the third ventricle region causing mass effect on aqueduct and moderate-to-severe hydrocephalus. 


\section{BMJ Case Reports}

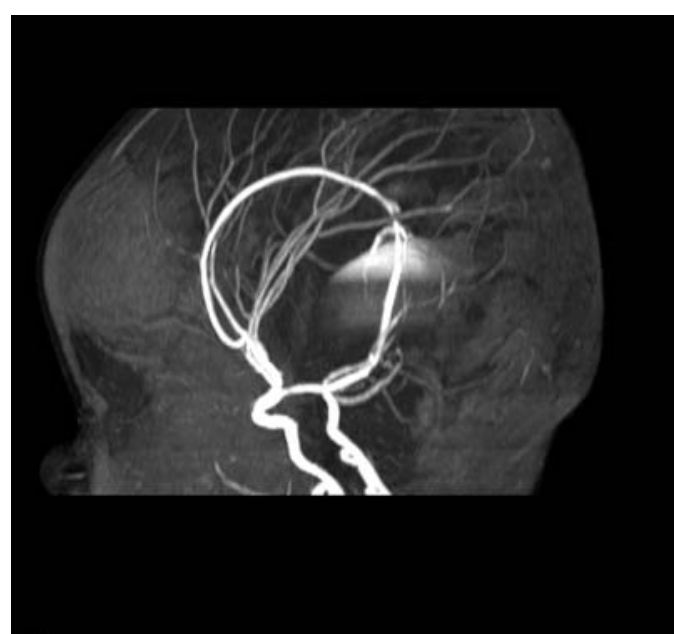

$\mathbf{a}$

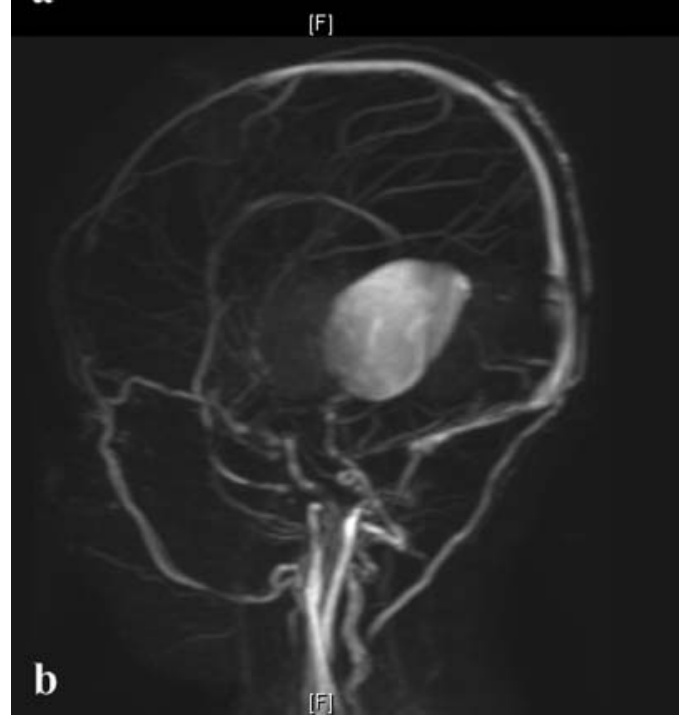

Figure 2 ( $A$ and $B)$ : MR angiography and venography showing the relationship of vein of Galen malformation with the adjacent vascular structures, arterial supply and venous drainage.

\section{Learning points}

- Vein of Galen aneurysmal malformation (VGAM) can present as macrocephaly or cardiac failure.

- MRI is a useful investigation for the evaluation of VGAM.

- Treatment options for VGAM include embolisation or surgical correction.

\section{Competing interests None.}

Patient consent Obtained.

\section{REFERENCES}

1. Raybaud CA, Strother CM, Hald JK. Aneurysms of the vein of Galen: embryonic and anatomical features relating to the pathogenesis of the malformation. Neuroradiology 1989;31:109-28.

2. Balakumar K. Antenatal diagnosis of vein of Galen aneurysm-case report. Ind J Radiol Imag 2003;13:91-2.

3. Beltramello A, Perini S, Mazza C. Spontaneously healed vein of Galen aneurysm. Childs Nerv Syst 1991;7:129-34.

4. Lasjaunias P. Vein of Galen aneurysmal malformation. In: Vascular disease in neonates, infants and children. Berlin: Springer-Verlag, 1997: 67-202.

5. Mitchell PJ, Rosenfeld JV, Dargaville P, et al. Endovascular management of vein of Galen aneurysmal malformations presenting in the neonatal period. Am J Neuroradiol 2001, 22:1403-9.

This pdf has been created automatically from the final edited text and images.

Copyright 2012 BMJ Publishing Group. All rights reserved. For permission to reuse any of this content visit http://group.bmj.com/group/rights-licensing/permissions.

BMJ Case Report Fellows may re-use this article for personal use and teaching without any further permission.

Please cite this article as follows (you will need to access the article online to obtain the date of publication).

Ahmad M, Mir S, Wahab S, Rizvi I. Vein of Galen malformation. BMJ Case Reports 2012;10.1136/bcr-2012-006822, Published XXX

Become a Fellow of BMJ Case Reports today and you can:

- Submit as many cases as you like

- Enjoy fast sympathetic peer review and rapid publication of accepted articles

- Access all the published articles

- Re-use any of the published material for personal use and teaching without further permission

For information on Institutional Fellowships contact consortiasales@bmjgroup.com

Visit casereports.bmj.com for more articles like this and to become a Fellow 